\title{
Shopping Centres and Intangible Consumption in Global Cities
}

\author{
Margherita Corniani*
}

\begin{abstract}
In global markets, shopping centres are becoming important agents, defining the kind and quality of intangible features of supplies, not only establishing the assortments, but also affecting the consumption behaviour atmosphere that they determine in all its aspects. In this way, shopping malls are responsible for the quality of the intangible consumption process which has a profound impact on people and on the community that people live in. That is why shopping centres, both physical and virtual (i.e. e-commerce sites and other kinds of virtual marketplaces), are significant in big towns, where commercial density is high.

By defining the intangible aspects of consumption, shopping centres determine the development of a particular geographical area (normally surrounding a big city) because they are able to concentrate demand, and they play an active role in establishing the choice alternatives, which means forging the consumption habits and expectations of populations and cities.
\end{abstract}

Keywords: Shopping Centres; Global Competition; E-Commerce; Intangible Consumption; Global Cities

\section{The Materiality and Intangibility of Supply and Consumption in Global Markets}

In recent decades, in global markets, 'intangible aspects' of supplies have been identified as determinants in the buying behaviour of many products (Brondoni, 2000-2001). As a matter of fact, for many product classes the material component of supplies tends to conform to common standards (the degreasing power of the molecules in most detergents on the market is similar, because the chemical components of the products are similar - or identical) while the distinctive factors of supply are concentrated in less material aspects like the design of the package (look, colour, etc.) and the brand. Take the example of a computer, a cell phone, a lamp, a watch or a pen. For each of these product types, the material aspects are substantially similar, where they are not identical, for products from different brands. What does

*Associate Professor of Management, University of Milan-Bicocca (margherita.corniani@unimib.it)

Edited by: ISTEI - University of Milan-Bicocca

ISSN: 1593-0319

Corniani Margherita, Shopping Centres and Intangible Consumption in Global Cities, Symphonya. Emerging Issues in Management (symphonya.unimib.it), n. 1, 2011, pp. 41-54

http://dx.doi.org/10.4468/2011.1.05corniani 
distinguish the various supplies is the system of intangibles (brand, design, distribution system, etc.).

The over-abundance of goods on offer and the basic condition of saturation of the consumption needs of the public is a feature of many over-supplied markets, where the purchasing and consumption process is guided not so much by the need for a product but rather by the desire to possess a specific product. In developed countries, the motivation that persuades a person to purchase a new pair of jeans normally is not linked to the elementary function of the trousers, i.e. to cover and protect, but rather to the desire to own a specific pair of jeans of a particular colour, a certain cut and/or a given brand. This is equally true for foods, clothing accessories, cars, cell phones, and so on. A general and widespread focus on the immaterial components of supply is established in supply systems and consumer choices in which the offering companies have focused the differentiation of their products.

The immaterial component is therefore an increasingly exploitable aspect of product characterisation, whereas the immaterial component that guides alternative choices and appreciation by the public is less fungible. For companies, the choice of the types of immaterial components to associate with their products or base them on, and the means of marketing the products themselves, becomes decisive.

The exploitability of the material components of supply underlines the significance of the immaterial components and the immaterial connotation of much consumption. The gradual 'detachment' from the material component brings to the forefront immaterial aspects of consumption like the situation, the environment, etc.. These shift attention from the simple content of the product to the way it is consumed, radically modifying the priorities for companies in their management of relations with the market. What counts, for example, is less the food we eat (although it must be good, with a chain that guarantees the quality and genuineness of the production process according to set parameters) than the context and means where we consume it: the eating place, the type of service, the environment (the room and its characteristics, garden, terrace, temperature, noise/silence, ambient smells), ease and serenity of access (parking, security for the car, personal security, child care, etc.). We can eat the same dish anywhere, so the difference must lie in the immaterial conditions, which distinguish between similar forms of consumption.

The competitive capabilities of manufacturing and commercial companies therefore shift from the simple delivery of material products to the suitable combination of material and immaterial factors, creating supply systems characterised by competitive customer value, i.e. a value perceived by the clientele that is higher than that of competing supplies (Riboldazzi 2005).

As a result, the place and manner of purchasing and consumption must also be seen as components of the supply system, helping to define a product for both its material and its immaterial aspects. The purchasing and consumption experience therefore enhances the immaterial consumption that develops in a region, with positive or negative repercussions for the population.

\section{Purchasing Locations and Intangible Consumption}

Where the processes of purchasing and immaterial consumption are concerned, cities tend to offer a concentration of numerous heterogeneous opportunities for consumption that may be defined at very different levels of quality. 
Physical sales outlets like shops and all the traditional retail outlets (boutiques, department stores, self-service stores, supermarkets, hypermarkets, category killers, discount stores, flagship stores, natural shopping centres, shopping centres, etc.) are now joined by virtual marketplaces where endless types of goods can be purchased with no direct contact with the corporate supply, right up to collection or delivery. These include the well-known sites of EPrice, Amazon, CDnow (Hoffman D. L. Novak T. P. 2000), etc. All these physical or virtual locations allow contact between the seller and the purchaser, who are thus given access to broad communities of individuals, meeting and relating with them in different ways (Brynjolfsson E. Smith M.D. 2000).

The same products can be sold and purchased in both types of location, whereas the immaterial aspects of consumption associated with these commercial processes are different and heterogeneous from one location to another. This underlines the substantial exploitability of the material component of supply and consumption, and the significance of the immaterial component as part of the purchasing and the consumption experience. White and brown home appliances, food, books, films, music, clothing and services can all be purchased in both types of location and, as a whole, the same identical products are accessible in nearly all these locations, but the context and system of the immaterial factors that distinguish the purchasing and/or consumption processes that could arise are different: transfers, car parks, child care, noise, smell, crowding, rest areas, means of payment, transport and delivery of purchases, etc.

\subsection{Shopping Centres as Venues for the Physical Concentration of Customers}

Shopping centres draw together different commercial activities in a context designed to foster consumption and comparisons between alternative products. They have evolved from the traditional local markets and are located in places that favour the encounter between demand and supply. Cities have set aside specific areas and structures to host, organise and simplify the sale and consumption processes, and to control the operators that go there. For example, the bazars found in all the main cities of the Middle East and North Africa, like those in Istanbul, Damascus, Aleppo, etc. all complete with roofs, walls, doors, and opening and closing times, where different types of product coexist (perishable goods, capital assets, clothing, furnishings, jewellery, catering and personal care, etc.), with common services like cleaning and surveillance. The urbanisation that has taken place in numerous cities around the world since the start of the last century, has resulted in growing concentrations of people in urban contexts, drawn by the job opportunities guaranteed by the presence of manufacturing activities (Merts J. E. 1949). The concentration of the demand for various types of goods and services has driven targeted investment to concentrate in natural and purpose-built locations even the commercial activities that previously occupied specific streets and districts of the towns (high streets or natural urban shopping precincts) and then chose to occupy places expressly designed for commercial activities. These were initially in towns (purpose-built urban shopping centres) but then, as towns expanded, so did their attraction over their peripheral area, and driven by the rising cost per square metre in urban areas, the shopping precincts spread to the suburbs of the world's major cities (purpose-built peripheral and out-of-town shopping centres) (Cohen L. 1996; Judd D. R. 1995). 
Of course, these types of shopping centres differ for numerous material and immaterial characteristics (size, access, security, environmental/climatic conditions, accessory services, etc.) which, in general terms, stem from the different origins of the various shopping centres. Natural urban shopping centres develop in or close to the town centre, out of the vicinity of various commercial activities that have developed in specific streets characterised by the presence of traffic, i.e. the frequent transit of potential customers. In time, in several cases, establishments in natural urban shopping precincts have joined together to try to coordinate services that are shared by all the shops, for example, street cleaning, lighting, Christmas lights, etc., as some of the world's main shopping streets have already done.

These centres have been joined by purpose-built shopping centres, where a promoter invests in a property development destined to collect a variety of commercial enterprises, according to assortment criteria designed to create a complex supply system that can attract numerous subjects.

$\square$ Usually (CNCC 2011), purpose-built shopping centres can be defined by their size, dividing them into neighbourhood or local shopping centres (GLA - Gross Leasable Area of up to 5,000 $\left.\mathrm{m}^{2}\right)$; small centres ( $G L A$ between 5,000 and 19,999 $\mathrm{m}^{2}$ ); medium sized centres (GLA 20,000-39,999 $\mathrm{m}^{2}$ ); large shopping centres (GLA between 40,000 and $\left.79,999 \mathrm{~m}^{2}\right)$; and large regional shopping centre (GLA of more than $80,000 \mathrm{~m}^{2}$ ). Another important criterion distinguishes shopping centres by their location, which may be: urban, in the centre of town with a high commercial density; suburban, i.e. in a semi-central area of town or on the edge of the built-up area, and therefore with a limited commercial density; or out-of-town, serving several towns, in areas with a low commercial density but good communications. And finally, commercial centres may be divided into single use, i.e. a centre in a development built to contain only the shopping centre, or multiple use (also defined as a multipurpose complex), where the shopping centre is part of a multipurpose real estate complex, for example containing residential, managerial, public services, hotels and sports or other facilities.

Shopping centres are often created around an anchor store that represents the main attraction for the clientele. Shopping centres often have a supermarket as their anchor, but a growing number of themed centres are developing, addressing specific market targets, where the anchor may be a multiplex cinema, entertainment or fitness facilities, plus, obviously, a significant number of catering establishments, for example Disneyland, Gardaland, Amsterdam Arena (Markerink, Santini 2004), etc..

On the whole, these centres are built in covered complexes with common services for participating businesses and the clientele: car parks, logistic facilities such as loading and unloading bays, warehouses, lifts, heating and air conditioning, cleaning, security, bathrooms, children's entertainment, etc. (Gruen V. 1943; Bernard J. F., Sagalyn L. B. 1989). However there are also outdoor retail parks, with a number of connected structures that form a sort of small town, with streets, squares, controlled access, security, etc., usually located out of town (Pleskach J. S. 1974; Rubenstein H. M. 1992). This is often the format chosen by Factory Outlets, where a number of 
different manufacturers market remainders, returned goods, experimental lines and excess output by their brand in their own stores.

Purpose-built shopping centres also include the stores and eating places incorporated into the waiting and rest areas of the transport and road network. Today, service stations on motorways, railway stations, airports, etc. all over the world are important concentrations of commercial activities, and the eating places that were traditionally the main attraction of these places are rapidly becoming a less important element of their turnover.

\begin{abstract}
$\square$ 'Autogrill began to provide catering services along the Italian motorways, before expanding abroad and gradually diversifying its presence, even through acquisitions, in railway stations and airports, becoming the world's leading operator in catering services for the traveller.' Autogrill revenues are generated $45 \%$ in North America, $33 \%$ in Italy and the remaining $22 \%$ in the rest of the world, through the following channels: motorways, airports, railway stations, shopping centres, cities and fairs (www.autogrill.it).
\end{abstract}

\begin{abstract}
$\square$ Grandi Stazioni Spa is a Ferrovie dello Stato Italiane company, owned $40 \%$ by Benetton, Caltagirone and Pirelli, with a lesser interest in the hands of the French company SNCF. It was created to regenerate and manage the commercial aspects of the railway stations in Italy's major cities, and has also won tenders to manage the commercial aspect of numerous stations abroad. In 2009 operating revenues exceeded $€ 183$ million, with a net profit of $€ 37.5$ million (www.grandistazioni.it).
\end{abstract}

These commercial and social structures established in travelling places (stations and highways) respect logics that are very similar and in some ways complementary to those of 'traditional' purpose-built shopping centres. Like the latter, they are built in locations with very high potential people traffic (such as the world's airports). However, people in transit are usually not in these locations so much to purchase as to travel, but they have time to spare, imposed by the transport system (connections, delays, etc.) and this can be dedicated to rest or to more profitable (for the commercial enterprises) and entertaining moments of recreation and shopping. This has led to a gradual evolution of transit structures from 'waiting' areas (with easy to reach waiting rooms positioned close to the departure areas of buses, ferries, trains and aircraft) to 'purchasing and consumption' areas, eliminating the waiting rooms altogether, or disseminating them among endless commercial proposals for all tastes and all pockets.

Shopping centres, whether high streets or purpose-built, share the goal of attracting clients in order to generate selling conditions for the stores in the centre. The related services can therefore be seen as immaterial factors of the complex supply system created to attract the public. The significance of the immaterial factors in the purchasing and consumption process potentially increases the role of shopping centres in the development of the town enormously, and in large cities in particular. The traditional social meeting places that caused cities to grow (in terms of covered area, population and wealth produced and consumed) and typically originated from a mixture of economic and religious activities (the main square, commercial and 
religious life, and the high street), are now tending to be replaced to a large extent by shopping centres. Consumption, and the purchasing activity that precedes it, tends to become crucial in global markets, while purchasing and consumption centres, like shopping centres, become the economic and social meeting places. But what is significant in these places is not so much the material aspect of the products available that can be enjoyed there, but the system of immaterial factors that characterises the consumption experience. This is linked to both the immaterial component of supply (for example, the presence of well-known brands) and the immaterial content of a specific type of supply (access to a cinema, a spa, fitness centres, recreation and social areas like food halls).

Naturally, the assortment of products in a shopping centre is the result of numerous factors; first of all the commercial catchment basin, its economic characteristics (spending capacity of the population, average age, culture, capacity for movement, commercial density, local infrastructure, etc.), but also the growth potential that it can guarantee to a specific area in economic, social and cultural terms. Any project to create a shopping centre and the choice of the mix of stores and social facilities, must be able to predict how the town and its surrounding territory will evolve, and to plan the type of development that it intends to guarantee in a specific territory in relation to the surrounding areas.

$\square$ For example, in Europe, the expansion policy of mass market retailers includes specific spaces for the supply of petroleum fuels. Indeed, very large retailers ( $c f$. Carrefour) also become gasoline distributors.

In the 60s, the first chains to open in Italy chose to locate in the city centre, without parking facilities, and just some pioneers chose spaces with parking facilities; today, the practice is to search for wider spaces, for easy parking, but also in order to allow trucks, needed to delivery gasoline, to maneuver adequately. So the areas for shopping centres tend to be larger and larger, and, as a consequence, are located in peripheral areas.

This means defining in advance the level of consumption that a given area can support, and understanding the level of qualitative development (normally associated with economic development and greater commercial and cultural wealth in the area itself) that may be reached, and when, by a given region, in order to understand the best type of investment and the characteristics of the economic return that it will generate.

$\square$ Size is a key variable in the classification of shopping centres around the world, and although the majority of the world's shopping centres are small (between $S F$ - square feets - $O$ and 50,000), the larger centres (over SF 1 million) account for 38\% of global GLA (De Lisle 2009). 
Chart 1: Global Shopping Centre Directory, 2009, Regional Composition

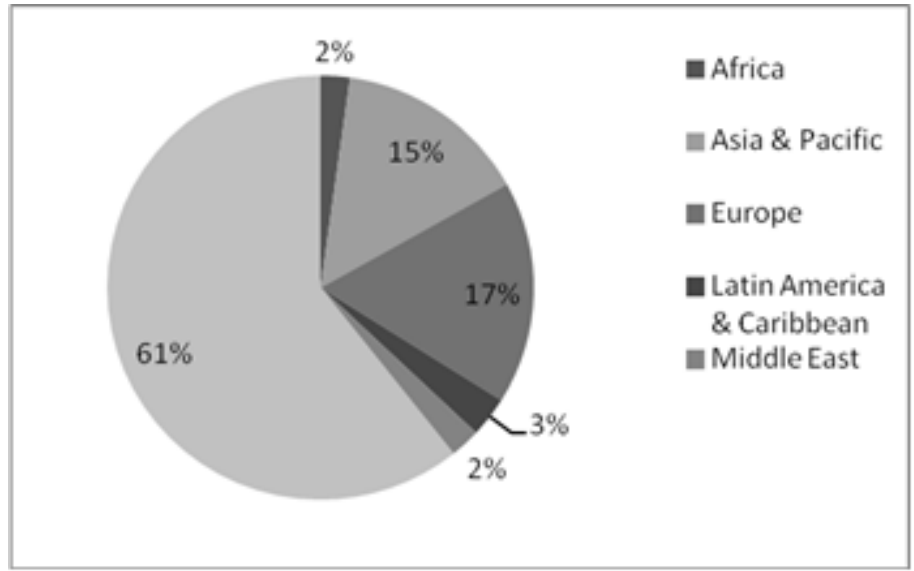

Source:http://icsc.org

Table 1 - Comparison between the World's Largest Shopping Centres

\begin{tabular}{|c|c|c|c|c|}
\hline Shopping Mall & $\begin{array}{l}\text { Opening } \\
\text { year }\end{array}$ & $\underset{\mathbf{m}^{2}}{\mathbf{G L A}}$ & $\begin{array}{r}\text { Total } \\
\text { area } \mathbf{m}^{2}\end{array}$ & $\begin{array}{l}\text { No. of } \\
\text { stores }\end{array}$ \\
\hline $\begin{array}{c}\text { South China Mall, Dongguan, } \\
\text { China }\end{array}$ & 2005 & 660,000 & 892,000 & 1,500 \\
\hline Jin Yuan, Beijing, China & 2004 & 560,000 & 680,000 & 1,000 \\
\hline $\begin{array}{l}\text { SM Mall of Asia, Pasa City, } \\
\text { Philippines }\end{array}$ & 2006 & 386,000 & & \\
\hline Dubai Mall, Dubai, UAE & 2008 & 350,000 & 550,000 & 1,200 \\
\hline $\begin{array}{l}\text { West Edmonton Mall, Edmonton, } \\
\text { Alberta, Canada }\end{array}$ & 1981 & 350,000 & 490,000 & 800 \\
\hline $\begin{array}{c}\text { Cevahir Istambul, Istanbul, } \\
\text { Turkey }\end{array}$ & 2005 & 348,000 & 420,000 & 280 \\
\hline $\begin{array}{l}\text { SM City North Edsa, Quezon } \\
\text { City, Philippines }\end{array}$ & 1985 & 332,000 & & 900 \\
\hline $\begin{array}{l}\text { SM Megamall, Mandaluyon City, } \\
\text { Philippines }\end{array}$ & 1991 & 332,000 & & 600 \\
\hline $\begin{array}{l}\text { Berjaya Times Square, Kuala } \\
\text { Lumpur, Malaysia }\end{array}$ & 2005 & 320,000 & 700,000 & 1,000 \\
\hline Beijing Mall, Beijing, China & 2005 & 320,000 & 440,000 & \\
\hline $\begin{array}{l}\text { Zhengjia Plaza, Guangzhou, } \\
\text { China }\end{array}$ & 2005 & 280,000 & 420,000 & \\
\hline $\begin{array}{c}\text { SM City Cebu, Cebu City, } \\
\text { Philippines }\end{array}$ & 1991 & 267,000 & & \\
\hline $\begin{array}{l}\text { Mall of America, Bloomington, } \\
\text { Minnesota, USA }\end{array}$ & 1992 & 260,000 & 390,000 & 520 \\
\hline $\begin{array}{l}\text { South Coast Plaza, Costa Mesa, } \\
\text { California, USA }\end{array}$ & 1967 & 250,000 & & 280 \\
\hline $\begin{array}{l}\text { Millcreek Mall, Erie, } \\
\text { Pennsylvania, USA }\end{array}$ & 1975 & 242,000 & & 142 \\
\hline $\begin{array}{c}\text { Central Commercial Santafe, } \\
\text { Bogota, Colombia }\end{array}$ & 2006 & 250,000 & & 485 \\
\hline $\begin{array}{c}\text { Aricanduva Mall, San Paolo, } \\
\text { Brazil }\end{array}$ & 1991 & 242,000 & 342,000 & 535 \\
\hline $\begin{array}{l}\text { Chia Tai Square, Shanghai, } \\
\text { Jiangsu, China }\end{array}$ & 2005 & 240,000 & & \\
\hline $\begin{array}{c}\text { Siam Paragon, Bangkok, } \\
\text { Thailand }\end{array}$ & 2005 & 230,000 & 380,000 & \\
\hline $\begin{array}{c}\text { Del Amo Fashion Center, Los } \\
\text { Angeles, Ca, USA }\end{array}$ & 1975 & 230,000 & & 300 \\
\hline
\end{tabular}

Source: Shopping Centre Studies at Eastern Connecticut State University, June 2011. 


\subsection{Virtual Marketplaces and Clientele Aggregation}

However, in global marketplaces, purchasing and consumption are not limited to a traditional 'physical' form as they are in shopping centres, but can take place in virtual locations, which have attracted and maintained contacts with a very high number of clients and visitors in the last thirty years. The first virtual purchasing and consumption 'locations' developed in the form of virtual marketplaces, where sellers and customers can meet to buy and sell, both with the mechanism of the traditional fixed price, and with various forms of auction (ascending, descending, etc.) (Reinartz 2002). One well-known global example is E-bay, the online auction site where it is possible to buy and sell practically everything, new and second-hand, at any price level. In addition to these forms of encounter between supply and demand (many of which have developed in the context of B2B markets), other virtual 'locations' have evolved as proper e-commerce sites. The first forms of online purchases were those created by manufacturing companies which, after having opened an internet site to present their activities, tried to extend their conventional selling channels (singlebrand stores, boutiques, retail chains, etc.) to the electronic channel, creating online shop windows and developing e-commerce portals to manage new and different ways of relating with their customers.

Management of customer relations was also exploited by other companies that preferred online trading, developing relations with selected suppliers and promoting products through a pool of customers who are registered on the site and interested in specific types of products and economic conditions. This latter type of marketplace corresponds in many ways with the traditional shopping centre, albeit with a number of different elements. However it certainly contributes to the development of immaterial consumption, starting from immaterial mechanisms to purchase and pay for goods, with significant repercussions for the towns served.

The business formula on which the online trading sites are based, is the capacity to establish relations with specific suppliers (usually manufacturers of products with brands that are familiar in different commodity classes such as high-tech, clothing, accessories, etc.), to negotiate advantageous supply conditions, and thus to promote brand products among its clients. These normally coincide with a self-selected public, who register with specific internet sites. In particular, the advantages provided by these sites are the offer of products at large discounts (even as much as $70 \%$ on the market price) and delivery of the customer's purchases to his home or to specific collection points.

In other words, it is a question of managing the combination between the system of relations with suppliers and that with the clientele, designing combinations of products that can attract customers, stimulating them to purchase and to return frequently to the site. On the supply relations front, these companies establish monopolistic relations based on companies, brands and products, agreeing lots of a specific size that the supplier undertakes to hold in its own warehouses for a finite period of time, usually very short (often less than a week). They normally refer to manufacturing lines created specifically, not destined to traditional selling channels, or to products from a previous collection that are no longer present (or no longer crucial) in the assortment of the traditional channels. In view of these conditions it is still possible, for a set period of time, to guarantee clients a high percentage discount compared to similar products sold through the traditional physical channel. On the 
other hand, when he is aware of the site and its potential advantages, a customer registers and provides the trader with the first profiling elements (elementary socioeconomic-demographic data). He thus enters the 'community' and can surf the site looking for purchasing offers and proposals whenever he wants, as well as receiving information about offers and novelties by email. Naturally, the customer's profile created by the trader is backed up by all the information that the customer himself transmits as he navigates the site with his own user ID, making purchases. The wealth of information that is generated enables the trader to define his assortment, the geographical area to cover, the prices to propose, and the type of communication to undertake, in other words the demand bubbles to create (Corniani 2002).

$\square$ 'Such a system creates value for a business as a consequence of the
value it delivers to users - personalised purchase recommendations,
connections between buyers and sellers of hard-to-find items, new
personal or business relationships, lower prices, membership in a
community, entertainment, information of all kinds.' (Cook 2008, 63).

On the other hand, for the trader, the large number of people registered with the site represent not only a known pool of potential customers who can be reached at no cost, but also a product to sell to supplier companies, in other words, a key factor in the negotiation process to obtain exclusives, discounts and supply conditions.

However, not all the online trading sites adopt the same business formula. Some chose the association form, for which free registration is necessary in order to access information about the advantageous conditions of the site; others offer free consultation to everyone and only require intending purchasers to register. In the first case, in particular, access by registration prevents the information present in the site from being analysed and quoted by search engines, making it possible to defend two parallel markets: the familiar market of traditional offers at 'market' prices, and the online market, with advantageous discounts and conditions, which is only open to those who register. In the case of trading sites open to all, the information on the site is also recorded by search engines and this therefore induces strong competition between alternative sites which, nonetheless, do offer advantageous economic conditions compared to conventional purchasing.

The online selling system created by the trading sites mentioned above can naturally be developed on a global scale (as Amazon, CDnow and numerous other sites do), in other words, regardless of the physical geographical location of suppliers and users/customers. This is made possible by a product supply system (publishers, bookshops and individuals) and logistic services that extend all over the world. However, numerous trading sites choose to concentrate on a specific area, i.e. with targeted supply relations and contacts with the clientele that are not found in other countries around the world. This is the case with sites like Eprice, Privalia, Yooks, Vente Privée and numerous others which, although virtual, have a very close link with the area they serve. The repercussions of this trading formula for the territory are therefore local and circumscribed and it is significant to include them among the structures that generate immaterial consumption and whose effects can be felt in the towns. 
Table 2: The First 30 European Multichannel Companies by Sales, 2010

\begin{tabular}{|c|c|c|c|c|c|}
\hline & Company & Country & & Company & Country \\
\hline 1 & Otto & $\mathrm{D}$ & 14 & ASDA & UK \\
\hline 2 & Tesco & UK & 15 & Ocado & UK \\
\hline 3 & $\begin{array}{l}\text { PPR (Fnac.com, } \\
\text { Laredoute.fr) }\end{array}$ & $\mathrm{F}$ & 16 & $\begin{array}{l}\text { Shop Direct } \\
\text { Group }\end{array}$ & $\overline{\mathrm{UK}}$ \\
\hline 4 & $\begin{array}{l}\text { Home Retail } \\
\text { Group }\end{array}$ & UK & 17 & John Lewis & UK \\
\hline 5 & 3 Suisses & $\mathrm{F}$ & 18 & $\begin{array}{l}\text { Marks \& } \\
\text { Spencer }\end{array}$ & UK \\
\hline 6 & Cdiscount & $\mathrm{F}$ & 19 & eBuyer UK & UK \\
\hline 7 & $\begin{array}{l}\text { Neckermann } \\
\text { Gruppe }\end{array}$ & $\mathrm{D}$ & 20 & Misco & UK \\
\hline 8 & $\begin{array}{l}\text { Dixons Stores } \\
\text { Group (di cui } \\
\text { Pixmania) }\end{array}$ & UK & 21 & $\begin{array}{l}\text { Conrad } \\
\text { Holding }\end{array}$ & $\mathrm{D}$ \\
\hline 9 & Carrefour & $\mathrm{F}$ & 22 & Play.com & UK \\
\hline 10 & Vente-privee.com & $\mathrm{F}$ & 23 & $\begin{array}{l}\text { The } \\
\text { Carphone } \\
\text { Warehouse } \\
\text { Group }\end{array}$ & UK \\
\hline 11 & Sainsburys & UK & 24 & Darty.com & $\mathrm{F}$ \\
\hline 12 & MediaShopping.it & I & 25 & Wehkamp & NL \\
\hline 13 & Next & UK & & & \\
\hline
\end{tabular}

Source: Internet Retailer, Netcomm Forum 2011.

In particular, the business formula of these trading structures is often based on the absence of warehouses and the ability to manage the relationship between supplier and customer, avoiding the transfer of ownership and the physical presence of the goods in the hands of the trader. However, even in Amazon's case, competitive pressure on delivery times and guaranteed respect of specifications and deadlines has induced many traders to choose a mixed solution, setting up a few warehouses and purchasing lots from suppliers in order to guarantee larger margins for manoeuvre when fixing prices and the validity of offer conditions. There is evidence that this logistic choice has further strengthened the link between the trading site and the area served.

The link between many of these sites and the area is still stronger because it is linked to the recognition of the brands sold and their ability to attract customers. So in order to interest particular parties in purchasing a product from a given brand, the manufacturing company must have been able to establish its offer with those parties. This is achieved with the presence of brand products in traditional selling channels (the shop windows of stores that are fashionable or with high traffic) or in the main vehicles of corporate communication (advertising, publicity, etc.), provided the potential clientele is familiar with the 'market' price in order to appreciate the advantage of purchasing at a discount online. A connection between online trading sites and traditional sales outlets (specialists, flagship stores, etc.) is therefore essential to boost the value of the online offers and it obviously links the trading sites with specific local areas, in particular with central areas that affirm brand awareness and image, like the high commercial density systems of large cities. 
$\square$ A European study quotes the following online sales by country in 2010 in Euro/billion: United Kingdom 69.4, France 31, Germany 25.3, Netherlands 8.2, Spain 7.3 and Italy 6.6 (Fevad. www.fevad.fr).

The pervasiveness of the offer represented by e-commerce sites and their link with the area are increasingly significant in global markets, but the main effects of their business can be seen in large cities, where the highest quantities of goods handled and people served are concentrated. Deliveries of goods purchased online are an essential aspect adopted by customers to assess the effectiveness and efficiency of the entire e-commerce process (Collier, Bienstock 2006). The majority of these sites are located where the commercial density is highest, with the availability of innovative, convenient purchasing and consumption services, prompting the complex system of players present in the region to increase the immaterial aspects of their products.

\section{Emerging Issues}

Shopping centres that combine purchases and consumption therefore tend to have a considerable impact on the towns where they are located, from numerous viewpoints, some strictly material that can be verified and measured immediately, and others less material whose effects will only be verified in time.

With regard to the former aspect, i.e. those most strictly material, 'physical' and virtual shopping centres both generate flows of goods and people, both with reference to the logistic entry system, i.e. related to the supply system, and with regard to selling processes, therefore in relations with customers. For a physical shopping centre, but in part also for a virtual retailer, the choice of a specific geographical location determines a basin of potential demand, with a purchasing and consumption capacity that is clearly defined in quantitative and qualitative terms. But this potential clientele is the condition that determines the best assortment. The clientele is therefore judge and cause of the assortments chosen by the companies, where assortment refers to the overall sum of products that each one of the many firms operating in the area intends to propose. In the case of virtual traders, the assortment is the sum of product ranges handled by each site, while in the case of town centre and purpose-built shopping centres, they identify the mix of shops located in the shopping centre with their specific assortment of brands. The clientele that can be reached by the location of a given shopping centre, or the opening of an Internet site to serve specific geographical areas, is therefore the framework parameter for the business and it is what the operator of a virtual trading site or a physical shopping centre can sell to his suppliers.

Of course, the clientele of a given region is exposed to the commercial stimuli of all the physical or virtual shopping centres that exist in that region, and the competition system and commercial density of the area have a great deal of influence on the tenant mix of each shopping centre.

On the other hand, the intangible, or less tangible, aspects of the impact of the physical and virtual shopping centres in a region are more or less easily measured in the short term. But they are also very significant, with effects that tend to extend in the medium-long term. The immaterial component of purchase and consumption does not vanish at the moment of the purchase or consumption, but tends to trigger a 
contagious effect that stimulates new offers and prepares the public for new and more complex forms of consumption. In other words a habit is created and a taste for a particular immaterial aspect of consumption, which tends to recall and demand new immaterial elements and to increase the very immateriality of consumption.

When it is no longer the material components of the product that determine the purchase of a car, but immaterial components like the brand, before-sales relations, design, the warranty, maintenance and other after-sales services, etc., this underlines the substantial fungibility of the material components of the product, and the significance and unique nature of the various immaterial aspects. The public therefore learns to appreciate the immaterial alternatives of the products on the market and expects explicit investments in this direction from the system of salesmen, naturally taking for granted the qualitative and material factors of the tangible component of the product. The competitive system of production and sale must therefore be able to offer products that are increasingly standardised, personalising their immaterial components. In doing so, they must succeed in achieving economies in relation to both the material and the immaterial factors of their products.

Through the immaterial factors of supply, physical and virtual shopping centres attract and concentrate the public and develop relations that tend to last longer in time. Investment in this relationship depends on companies' ability to create competitive customer value for its own clientele, investing in immaterial competitive relationship factors. Where the product is concerned, it become essential to be present where the purchasing and 'traffic' processes concentrate, with competitive offers in a system where the competitive comparison is strengthened or reduced to a system. It is imperative to achieve economies of scale on the tangible product component, whether intrinsic to the product or related to the peculiar characteristics of the purchasing and consumption process. With regard to the final demand for consumption, the new models of aggregation favour the search for information and highlight the distinctive factors of the various solutions available, while the habits of the consumption processes change, being concentrated in physical or virtual spaces rather than on specific brands or offers. This therefore generates a substantial shift in loyalty from the brand to the 'brand site' that refers to both specific physical locations like shopping centres, outlets, etc. and to virtual locations like virtual marketplaces where the clientele develops the habit of surfing in search of interesting product solutions, because over time he has tested the value of the immaterial system that surrounds the material supply.

Particularly in the case of virtual marketplaces, the potential to concentrate supply and demand makes it possible to strengthen economies of scale, in supply relations and the management of customer relations, increasing the competitiveness of a supply system. On the other hand, this boosts the system of contacts with the public, increasing the client profiling systems, accentuating the two-way relations between supply and demand according to a model that influences customer satisfaction and customer loyalty to the 'brand site', minimising maintenance and relationship management costs.

Physical and virtual shopping centres therefore become the centre of immaterial consumption and set the level of this consumption, choosing the mix of immaterial factors to offer on the basis of a two-way relationship that informs and shapes the market, to acquire capabilities and needs that evolve and develop thanks to the presence of competitive products. So it is increasingly the corporate products that 
address the immateriality of consumption and establish the type of development that a city may pursue, according to a principle by which there is no limit to the development of the material component of consumption, above all in the competitive action and reaction that is generated between companies in situations of high commercial intensity like those of large cities. In this sense, we can grasp the principle of the long-term effect that the immaterial component of supply is able to generate, fuelling immaterial consumption that evolves and grows thanks to the presence of alternatives that form the humus for the development of large cities and the consumption that can take place there.

\section{Bibliography}

Borgers Aloys, Voster Cindy, Assessing preferences for mega shoppingcentres: A conjoint measurement approach, Journal of Retailing and Consumer Services, vol. 18, n. 4, 2011, pp. 322332.

http://dx.doi.org/10.1016/j.jretconser.2011.02.006

Brondoni Silvio M. (2000-2001), Brand Policy and Brand Equity, Symphonya. Emerging Issues in Management (symphonya.unimib.it), n. 1, 2000-2001, pp. 5-25.

http://dx.doi.org/10.4468/2001.1.02brondoni

Brynjiolfsson Erick, Smith Michael D., Frictionless Commerce? A Comparison of Internet and Conventional Retailers, Management Science, vol. 46, n. 4, 2000, pp. 563-585.

http://dx.doi.org/10.1287/mnsc.46.4.563.12061

CNCC (Consiglio Nazionale dei Centri Commerciali Italia), L'industria dei centri commerciali in Italia. The Shopping Centers Industry in Italy 2011.

Cohen Lizabeth, From Town Center to Shopping Center: The Reconfiguration of Community Marketplaces in Postwar America, American Historical Review, vol. 101, Oct, 1996, pp. 1050-81. http://dx.doi.org/10.2307/2169634

Collier Joel E., Bienstock Carol C., How do Customers Judge Quality in an E-Tailer, MIT Sloan Management Review, Fall, vol. 48, n. 1, 2006, pp. 35-40.

Cook Scott, The Contribution Revolution. Letting Volounteers Building Your Business, Harvard Business Review, October, 2008, pp. 60-69.

Corniani Margherita, Demand Bubble Management, Symphonya. Emerging Issues in Management (symphonya.unimib.it), n. 1, 2002, pp.87-98. http://dx.doi.org/10.4468/2002.1.08corniani

Dalmiglio Davide, Il mercato degli investimenti Retail nel 2010, in CNCC, L'industria dei centri commerciali in Italia. The Shopping Centers Industry in Italy 2011, 2011, pp. 38-40.

Damian Diana Simona, Dias Curto José, Castro Pinto José, The Impact of Anchor Stores on the Performance of Shopping Centres: the Case of Sonae Sierra, International Journal of Retail \& Distribution Management, vol. 39, n. 6, 2011, pp. 456-475. http://dx.doi.org/10.1108/09590551111137994

Frieden Bernard J., Sagalyn Lynne B., Downtown Inc.; How America Rebuilds Cities, MIT Press, Cambridge, MA, 1989.

Gruen Victor, Shopping Center, Architectural Forum, 78, May, pp. 101-103, 1943.

Hoffman Donna L., Novak T. P., How to Acquire Customer on the Web, Harvard Business Review, May-June, 2000, pp. 179-188.

Judd Dennis R., The Rise of the New Walled Cities. In: Liggett H., Perr D. C. (eds.), Spatial Practices, Thousand Oaks: Sage, 1995, pp. 144-168.

Liscia Roberto, Le nuove tendenze degli acquirenti on line, Netcomm Forum 2011, 2011.

Markerink Henk J., Santini Andrea, The Development of Stadiums as Centers of Large Entertainment Areas. The Amsterdam Arena Case, Symphonya. Emerging Issues in Management (symphonya.unimib.it), n. 2, 2004, pp. 47-72. 
http://dx.doi.org/10.4468/2004.2.04markerink.santini

Mertes J. E., The Shopping Center-A New Trend in Retailing, Journal of Marketing, vol. 13, Jan, 1949, pp. 374-379. http://dx.doi.org/10.2307/1248126

Panu Maddalena, Il mercato dei centri commerciali - Le statistiche, in CNCC, L'industria dei centri commerciali in Italia. The Shopping Centers Industry in Italy 2011, 2011, pp. 34-37.

Pitt Michael, Musa Zairul N., Towards defining shopping centres and their management systems, Journal of Retail and Leisure Property, vol. 8, 2009, pp. 39-55. http://dx.doi.org/10.1057/rlp.2008.25

Reinartz Werner J., Customizing Prices in Online Markets, Symphonya. Emerging Issues in Management (symphonya.unimib.it), n. 1, 2002. http://dx.doi.org/10.4468/2002.1.05reinartz

Riboldazzi Sabina, Global Retailers and Competitive Customer Value, Symphonya. Emerging Issues in Management (symphonya.unimib.it), n. 2, 2005, pp.77-87. http://dx.doi.org/10.4468/2005.2.07riboldazzi

Roberts Jane, Merrilees Bill, Herington Carmel, Miller Dale, Building retail tenant trust: neighbourhood versus regional shopping centres, International Journal of Retail \& Distribution Management, vol. 38, n. 8, 2010, pp. 597-612. http://dx.doi.org/10.1108/09590551011057426

Rubenstein Harvey M., Pedestrian Malls, Streetscapes, and Urban Spaces. New York: Wiley and Sons, 1992.

Tassinari Vincenzo, Retailers, Frontiers of Innovation and Local Legislative Constraints, Symphonya. Emerging Issues in Management (symphonya.unimib.it), n. 1, 2010, pp.18-22. http://dx.doi.org/10.4468/2010.1.03tassinari

Zanderighi L., Town Centre Management: uno strumento innovativo per la valorizzazione del centro storico e del commercio urbano, Industria \& Distribuzione, n. 2, 2001, pp. 27-37. 